\title{
THERAPEUTIC EFFECT OF NYMPHAEA ALBA LINN. FLOWERS AGAINST ISONIAZID-INDUCED HEPATOTOXICITY: AN EXPERIMENTAL STUDY
}

\author{
MOHAMMAD NASIRUDDIN ${ }^{1}$, IRFAN AHMAD KHAN ${ }^{1 *}$, SAYEEDUL HASAN ARIF ${ }^{2}$ \\ ${ }^{1}$ Department of Pharmacology, Jawaharlal Nehru Medical College, Aligarh, Uttar Pradesh, India. ${ }^{2}$ Department of Pathology, Jawaharlal \\ Nehru Medical College, Aligarh, Uttar Pradesh, India. Email: irfan1308@gmail.com
}

Received: 29 September 2017, Revised and Accepted: 12 February 2018

\section{ABSTRACT}

Objective: This study was designed to evaluate the effect of ethanolic extract of Nymphaea alba (NAEE) Linn. flowers on liver marker enzymes, histology, and antioxidant tests against isoniazid (INH)-induced hepatotoxicity in rats.

Methods: Wistar albino rats were treated with INH (50 mg/kg) for 28 days to induce hepatotoxicity. Silymarin (100 mg/kg) and NAEE Linn flowers in $200 \mathrm{mg} / \mathrm{kg}$ and $400 \mathrm{mg} / \mathrm{kg}$ doses, respectively, were used as standard and test drugs. Liver marker enzymes and histological examination of livers were performed to demonstrate the effect of NAEE against INH-induced hepatotoxicity. Catalase [CAT], glutathione, and malondialdehyde (MDA) levels were estimated to evaluate the antioxidant property of the NAEE extract.

Results: The NAEE extract in $200 \mathrm{mg} / \mathrm{kg}$ and $400 \mathrm{mg} / \mathrm{kg}$ doses significantly decreased INH-induced elevation of liver marker enzymes as well as oxidative stress markers (CAT, glutathione, and MDA) in rats. Changes in biochemical parameters were supported by histological improvements of the liver.

Conclusion: The NAEE Linn flowers in $200 \mathrm{mg} / \mathrm{kg}$ and $400 \mathrm{mg} / \mathrm{kg}$ doses showed a significant reversal of hepatic damage which was induced by INH in rats.

Keywords: Ethanolic extract, Nymphaea alba Linn., Flowers, Isoniazid-induced hepatotoxicity.

(C) 2018 The Authors. Published by Innovare Academic Sciences Pvt Ltd. This is an open access article under the CC BY license (http://creativecommons. org/licenses/by/4. 0/) DOI: http://dx.doi.org/10.22159/ajpcr.2018.v11i5.22830

\section{INTRODUCTION}

Tuberculosis is one among the oldest diseases known to affect the human being and is one of the major causes of death worldwide [1]. Isoniazid (INH) is the preferred drug in both chemoprophylaxis and treatment of tuberculosis [2,3]. Daily intake can lead to moderate elevation in liver enzymes and severe hepatic damage (especially, hepatic necrosis) in 3-20\% and $1-2 \%$ of patients, respectively $[3,4]$. Recent experimental studies have shown that one of the mechanisms responsible for INH-induced hepatic injury is oxidative stress. Free oxygen radicals may result in oxidative damage by lipid peroxidation. One of the aldehyde compounds generated from lipid peroxidation is malondialdehyde (MDA), which can be used to evaluate this damage [2]. The decrease of catalase (CAT) and glutathione (GSH) levels and increase of MDA level are closely related to oxidative stress, and the normalization of these levels by drugs or chemicals is extremely important for the attenuation of oxidative tissue damage [5-8].

Nymphaea alba Linn. (Nymphaeaceae) is mainly found in tanks and ponds throughout the warmer parts of India and Africa. The flowers are white, and they contain various phytoconstituents such as alkaloids, carbohydrates (polysaccharides), glycosides, steroids, flavonoids, tannin, and phenolic compound [9]. All parts of the plant have medicinal uses in the traditional system of medicine. It is employed as an antiinflammatory, anodyne, astringent, antiscrophulatic, cardiotonic, demulcent, sedative, and aphrodisiac. It also produces sedative and calming effects on the nervous system and is useful in the treatment of anxiety, insomnia, and similar disorders [10-12]. The leaves and rhizomes of $N$. alba possess antioxidant activity $[13,14]$.

The aim of the present study was therefore to investigate the therapeutic effect of ethanolic extract of $N$. alba (NAEE) Linn. flowers against INHinduced hepatotoxicity in rats.

\section{METHODS}

Institutional Animal Ethical Committee (IAEC) approval The Institutional Animal Ethics Committee approved the experimental protocol (Registration No. 401/Committee for the Purpose of Control and Supervision of Experiments on Animals (CPCSEA) dated 09.05.2012). All experiments were carried out in accordance with the rules and regulations of IAEC and CPCSEA.

\section{Preparation of extract}

The flowers of $N$. alba Linn. were procured from Dawakhana Tibbiya College, A.M.U., Aligarh, and identified by Prof. S. H. Afaq, Pharmacognosy Section, Department of Ilmul Advia, A.K.T.C., A.M.U., Aligarh, Uttar Pradesh, India. Shade-dried flowers were coarsely powdered and then subjected to extraction. Extraction of powder in ethanol was done $72 \mathrm{~h}$ using Soxhlet apparatus. The extract was filtered using Whatman No. 1 filter paper, evaporated on a water bath at $50^{\circ} \mathrm{C}$ until it dried completely, and stored in the refrigerator for further use. The yield of NAEE was found to be $10.6 \%$.

\section{Experimental animals}

Thirty-six healthy Wistar albino rats weighing 150-200 g of either sex procured from Central Animal House of the Institute were housed under standard condition (temperature $27 \pm 2{ }^{\circ} \mathrm{C}$, Humidity $30-70 \%$, and $12 \mathrm{~h}$ light/dark cycles) and fed with standard pellet diet and water ad libitum. All the animals were acclimatized to laboratory conditions for 1 week before the experimental procedure.

\section{Chemicals and drugs}

INH was acquired from Macleods Pharmaceuticals Ltd., Mumbai, Maharashtra, India. Silymarin was acquired from Micro Labs Ltd., Bengaluru, Karnataka, India. The aspartate aminotransferase (AST), 
alanine transaminase (ALT), alkaline phosphatase (ALP), and total bilirubin (TB) kit were purchased from Siemens, Mumbai.

\section{Experimental design}

The animals were divided in 6 groups comprising of 6 animals each. All drugs were administered orally. The groups were treated as follows:

- Group-I: Normal saline $(1 \mathrm{~mL} / \mathrm{kg})$ for 28 days.

- Group-II: INH (50 mg/kg) [2] for 28 days.

- Group-III: INH $(50 \mathrm{mg} / \mathrm{kg})$ for 28 days followed by normal saline $(1 \mathrm{~mL} / \mathrm{kg})$ for 15 days.

- Group-IV: INH $(50 \mathrm{mg} / \mathrm{kg})$ for 28 days followed by silymarin $(50 \mathrm{mg} / \mathrm{kg})[15]$ for 15 days.

- Group-V: INH ( $50 \mathrm{mg} / \mathrm{kg}$ ) for 28 days followed by NAEE Linn. flowers $(200 \mathrm{mg} / \mathrm{kg})$ for 15 days

- Group-VI: INH ( $50 \mathrm{mg} / \mathrm{kg}$ ) for 28 days followed by NAEE Linn flowers $(400 \mathrm{mg} / \mathrm{kg})$ for 15 days.

Animals were sacrificed under sodium pentobarbitone $(50 \mathrm{mg} / \mathrm{kg}$ intraperitoneally). Rats of Groups-I and II were sacrificed on the $29^{\text {th }}$ day, while animals of Groups III-VI were sacrificed on the $44^{\text {th }}$ day. Blood sample was taken by cardiac puncture for the estimation of liver function tests, and liver was dissected out for antioxidant tests and histological examination in each animal.

\section{Biochemical investigations}

The serum separated from blood was used for biochemical analysis of liver function (AST, ALT, and ALP) [16,17].

\section{Antioxidant tests}

The homogenate of the liver (in 10\% weight/volume of phosphate buffer [0.2 M, pH-6.6]) tissue was used to perform in vivo antioxidant tests such as CAT [18], reduced GSH [19], and MDA [20].

\section{Histological examination of liver}

The histological assessment of liver damage was done by scoring of structural changes described by the National Health Services, Maryland, USA [21]. The parameters were as follows: Degeneration $(0=$ no degeneration, $1=$ few vacuolated cells per lesion, $2=$ more than 10 vacuolated cells per lesion, $3=$ one to two rows of vacuolated cells around necrotic zone per lesion, and $4=$ more than two rows of vacuolated cells around necrotic zone per lesion), necrosis $(0=$ no necrosis, 1 = focal necrosis of one or two cells per lesion, 2 = focal necrosis of more than two cells per lesion, $3=$ massive centrilobular necrosis, and $4=$ massive centrilobular necrosis with necrotic tissue bridging the central vein), fibrosis $(0=$ normal appearance of liver, $1=$ central necrosis, hydropic degeneration, no fibrosis, 2 = fibrous tissue in periportal area only, $3=$ fibrous tissues insinuating surrounding hepatic parenchyma, and $4=$ formation of pseudo lobules), and regeneration $(0=$ no regeneration, $1=$ mild, $2=$ moderate, and $3=$ excellent).

\section{Statistical analysis}

The data were analyzed using one-way analysis of variance with post hoc Tukey test for biochemical parameters and Mann-Whitney U-test for comparing histopathology score. The values are represented as mean \pm standard error of mean. $\mathrm{p}<0.05$ was considered statistically significant.

\section{RESULTS}

\section{Effect of NAEE on biochemical tests}

The therapeutic effect of $N$. alba Linn. flowers was measured against INH-induced hepatotoxicity as shown in Table 1. Oxidative stress damages the integrity of liver cells and causes the release of enzymes sucha s transaminases (AST and ALT) and ALP as shown in Group-II (INH only). There was not any improvement in any of the parameters when normal saline was administered after INH (Group-III). Group-IV (INH + silymarin) showed a significant decrease in AST ( $\mathrm{p}<0.001)$, ALT levels ( $\mathrm{p}<0.001)$, ALP $(\mathrm{p}<0.01)$, and TB $(\mathrm{p}<0.01)$ as compared to GroupII. Group-V (INH + NAEE $200 \mathrm{mg} / \mathrm{kg}$ ) showed a significant decrease in AST ( $p<0.001)$, ALT levels $(\mathrm{p}<0.001)$, ALP $(\mathrm{p}<0.05)$, and TB $(\mathrm{p}<0.01)$ as compared to Group-II. Group-VI (INH + NAEE $400 \mathrm{mg} / \mathrm{kg}$ ) showed a significant decrease in AST $(p<0.001)$, ALT levels $(p<0.001)$, ALP $(\mathrm{p}<0.01)$, and TB $(\mathrm{p}<0.01)$ as compared to Group-II (Table 1$)$.

\section{Effect of NAEE on antioxidant tests}

In the experiment, the antioxidant activity was evaluated as the amount of CAT consumed per minute and total GSH present in liver tissue. There was a significant decrease in the levels and activity of GSH and CAT in INH alone treated group. NAEE 200 and $400 \mathrm{mg} / \mathrm{kg}$ showed an increase in the levels of CAT $(\mathrm{p}<0.001)$, thereby suggesting a correction in oxidative stress. There was a significant increase in the levels of GSH $(p<0.001)$ and a decrease in MDA $(p<0.001)$ levels in both NAEE 200 and NAEE 400 extracts treated groups as compared to negative control (Table 1).

\section{Effect of NAEE on histological findings}

INH administration in Group-II gave rise to necrosis, fibrosis, and degeneration of hepatic microstructure. In Group-III, there was degeneration along with bridging fibrosis of hepatic microstructure but no regenerating foci. Silymarin-treated group showed near normal hepatic microstructure. In NAEE-treated groups, there was increased regenerating foci (Fig. 1a-e). NAEE 200 and $400 \mathrm{mg} / \mathrm{kg}$ administrations resulted in a significant increase in regenerating foci and decrease in fibrosis and degeneration as compared to INH only group $(p<0.001)$ (Table 2).

\section{DISCUSSION}

Drug-induced hepatotoxicity is the serious adverse effect of the currently used antitubercular chemotherapeutic agents containing INH $(\mathrm{H})$, rifampicin, and pyrazinamide [2]. The serum levels of hepatic enzymes primarily reflect the degree of liver damage and have been

Table 1: Effect of NAEE Linn flowers on liver marker enzymes and oxidative stress markers against INH-induced hepatotoxicity in rats

\begin{tabular}{|c|c|c|c|c|c|c|}
\hline \multirow{2}{*}{$\begin{array}{l}\text { Biochemical } \\
\text { test (mean } \pm S E M)\end{array}$} & \multicolumn{6}{|c|}{ Groups $(n=6)$} \\
\hline & $\begin{array}{l}\text { Group-I } \\
\text { (normal } \\
\text { saline only) }\end{array}$ & $\begin{array}{l}\text { Group-II } \\
\text { (INH only) }\end{array}$ & $\begin{array}{l}\text { Group-III } \\
\text { (INH+normal saline) }\end{array}$ & $\begin{array}{l}\text { Group-IV } \\
\text { (INH+silymarin) }\end{array}$ & $\begin{array}{l}\text { Group-V } \\
\text { (INH+NAEE } 200 \text { mg/kg) }\end{array}$ & $\begin{array}{l}\text { Group-VI } \\
\text { (INH+NAEE } 400 \text { mg/kg) }\end{array}$ \\
\hline AST (IU/mL) & $38.4 \pm 1.5$ & $151.1 \pm 6.3^{z}$ & $149.9 \pm 6.9$ & $60.2 \pm 6.6^{c}$ & $84.4 \pm 7.9^{c}$ & $68.7 \pm 6.8^{c}$ \\
\hline ALT (IU/mL) & $39.8 \pm 1.6$ & $155.3 \pm 5.1^{z}$ & $152.2 \pm 5.5$ & $58.5 \pm 2.8^{c}$ & $81.1 \pm 4.5^{c}$ & $64.4 \pm 3.1^{c}$ \\
\hline ALP (KAU/dL) & $41.8 \pm 2.6$ & $79.6 \pm 5.5^{z}$ & $79.5 \pm 5.7$ & $50.2 \pm 4.7^{b}$ & $62.6 \pm 5.1^{\mathrm{a}}$ & $55.2 \pm 4.9^{b}$ \\
\hline $\mathrm{TB}(\mathrm{mg} / \mathrm{dL})$ & $0.363 \pm 0.032$ & $0.851 \pm 0.082^{z}$ & $0.795 \pm 0.084$ & $0.514 \pm 0.042^{\mathrm{b}}$ & $0.531 \pm 0.041^{\mathrm{b}}$ & $0.499 \pm 0.028^{b}$ \\
\hline $\mathrm{GSH}(\mu \mathrm{moL} / \mathrm{mg})$ & $5.29 \pm 0.29$ & $2.18 \pm 0.26^{z}$ & $2.30 \pm 0.25$ & $4.58 \pm 0.13^{c}$ & $4.22 \pm 0.19^{c}$ & $4.60 \pm 0.11^{c}$ \\
\hline MDA (nmoL/mg) & $204.8 \pm 8.9$ & $438.9 \pm 18.9^{z}$ & $430.1 \pm 17.6$ & $254.8 \pm 7.8^{c}$ & $277.4 \pm 10.7^{c}$ & $253.4 \pm 6.9^{c}$ \\
\hline
\end{tabular}

Values are expressed as mean \pm SEM. ${ }^{\mathrm{z}} \mathrm{p}<0.001$ when Group-II was compared with Group-I; ${ }^{\mathrm{a}} \mathrm{p}<0.05$, ${ }^{\mathrm{b}} \mathrm{p}<0.01$, and ${ }^{\mathrm{c}} \mathrm{p}<0.001$ when Groups IV-VI were compared with Group-II, NAEE: Ethanolic extract of Nymphaea alba, INH: Isoniazid, AST: Aspartate aminotransferase, ALT: Alanine transaminase, ALP: Alkaline phosphatase, TB: Total bilirubin, MDA: Malondialdehyde, GSH: Glutathione, CAT: Catalase 
Table 2: Effect of NAEE Linn. flowers on histopathology score against INH-induced hepatotoxicity in rats

\begin{tabular}{|c|c|c|c|c|c|c|}
\hline \multirow{2}{*}{$\begin{array}{l}\text { Parameter } \\
(\text { mean } \pm \text { SEM) }\end{array}$} & \multicolumn{6}{|c|}{ Groups $(n=6)$} \\
\hline & $\begin{array}{l}\text { Group-I } \\
\text { (normal } \\
\text { saline only) }\end{array}$ & $\begin{array}{l}\text { Group-II } \\
\text { (INH only) }\end{array}$ & $\begin{array}{l}\text { Group-III } \\
\text { (INH+normal saline) }\end{array}$ & $\begin{array}{l}\text { Group-IV } \\
\text { (INH+silymarin) }\end{array}$ & $\begin{array}{l}\text { Group-V } \\
\text { (INH+NAEE } 200 \mathrm{mg} / \mathrm{kg} \text { ) }\end{array}$ & $\begin{array}{l}\text { Group-VI } \\
\text { (INH+NAEE } 400 \mathrm{mg} / \mathrm{kg} \text { ) }\end{array}$ \\
\hline Degeneration & 0 & $2.9 \pm 0.4^{z}$ & $2.7 \pm 0.3$ & $0.6 \pm 0.01^{\mathrm{c}}$ & $1.2 \pm 0.08^{c}$ & $0.7 \pm 0.02^{\mathrm{c}}$ \\
\hline Necrosis & 0 & $2.1 \pm 0.3^{z}$ & $1.9 \pm 0.3$ & $0^{c}$ & $0^{c}$ & $0^{c}$ \\
\hline Fibrosis & 0 & $1.9 \pm 0.2^{z}$ & $1.7 \pm 0.2$ & $0.5 \pm 0.02^{c}$ & $0.8 \pm 0.09^{c}$ & $0.6 \pm 0.04^{c}$ \\
\hline Regeneration & 0 & 0 & 0 & $3.0 \pm 0.06^{c}$ & $2.8 \pm 0.24^{\mathrm{c}}$ & $2.9 \pm 0.09^{c}$ \\
\hline
\end{tabular}

Values are expressed as mean \pm SEM. ${ }^{\mathrm{z}} \mathrm{p}<0.001$ when Group-II was compared with Group I; ${ }^{\mathrm{p}}<<0.001$ when Groups IV-VI were compared with Group-II, NAEE: Ethanolic extract of Nymphaea alba, INH: Isoniazid
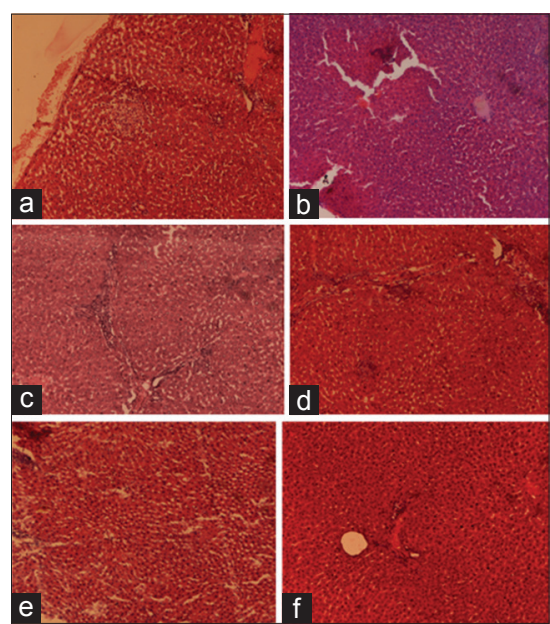

Fig. 1: (a) Photomicrograph of rat liver from Group-I (normal saline only) showing normal liver microstructure with intact hepatic cords and sinusoids. Hepatocytes show normal contour.

(H and $\mathrm{E}$ stain, $\times 10$ ), (b) photomicrograph of rat liver from Group-II (isoniazid [INH] only) showing necrosis, fibrosis, and degeneration of hepatic microstructure $(\mathrm{H}$ and $\mathrm{E}$ stain, $\times 10)$, (c) photomicrograph of rat liver from Group-III (INH + normal saline) showing degeneration of hepatic microstructure. There is also bridging fibrosis of hepatic microstructure (H and $\mathrm{E}$ stain, $\times 10$ ), (d) photomicrograph of rat liver from Group-IV (INH + silymarin) group showing maintained hepatic microstructure. There are also regenerating nodules $(\mathrm{H}$ and $\mathrm{E}$ stain, $\times 10),(\mathrm{e})$ photomicrograph of rat liver from Group-V (INH + ethanolic extract of Nymphaea alba [NAEE] $200 \mathrm{mg} / \mathrm{kg}$ ) showing occasional hepatocytic degeneration and fibrosis, along with a few regenerating nodules ( $\mathrm{H}$ and $\mathrm{E}$ stain, $\times 10$ ), (f) photomicrograph of rat liver from Group-VI (INH + NAEE $400 \mathrm{mg} / \mathrm{kg}$ ) showing evidence of maintained hepatic microstructure. There are abundant regenerating foci $(\mathrm{H}$ and $\mathrm{E}$ stain, $\times 10)$

frequently used as a diagnostic marker for hepatotoxicity [22,23]. INH $(50 \mathrm{mg} / \mathrm{kg})$ administration produced hepatotoxicity which was evident from the deranged biochemical and histological parameters.

INH is used extensively for prophylaxis as well as treatment of tuberculosis, but significant hepatotoxicity has often been reported. Hepatotoxicity after INH treatment is encountered in approximately $2 \%$ of cases, which if not recognized timely can have fatal outcome [24]. INH gets converted to acetylisoniazid by the enzyme $\mathrm{N}$-acetyl transferase- 2 which is eliminated by the kidney; acetylisoniazid is further transformed into acetylhydrazine and then to potential hepatotoxic metabolite acetyl diazine by the CYP enzymes which generates reactive acetyl onium ion, acetyl radical, and ketene, which causes irreversible damage to the liver tissue [25].

The NAEE Linn. flowers in $200 \mathrm{mg} / \mathrm{kg}$ and $400 \mathrm{mg} / \mathrm{kg}$ dose were therapeutically effective against INH-induced hepatotoxicity in rats. Both biochemical and histological parameters showed marked improvement with the restoration of liver functions. Both the doses decreased the derangement of liver function parameters, but this effect was more dominant in the high dose, i.e., $400 \mathrm{mg} / \mathrm{kg}$ dose group. Rats treated with NAEE showed significant reduction in the serum bilirubin, AST ALT, and ALP levels at both the doses. Since in Group-III there was no improvement in above parameters, it can be taken into account that the improvement in NAEE-treated groups was not due to self-healing process. There was further significant improvement in the antioxidants levels in NAEE-treated groups. This may be due to the prevention of lipid peroxidation as manifested by the decrease in MDA levels in NAEEtreated groups. The therapeutic benefit provided by NAEE was similar to that offered by the standard drug silymarin.

The findings of the biochemical analysis were further supported by histological examination of the liver tissues from the test group. NAEE in both the doses protected or maintained the liver tissue morphology evidenced by a reduction in the degeneration, necrosis, and fibrosis score in the histopathological examination. Regenerative nodules were likewise seen in the liver samples from both the test groups. Hence, the findings of the histological analysis also indicate that protection of the hepatocytes against damage induced by INH was significant in NAEEtreated groups. These findings were comparable to the prevailing drug silymarin.

One of the proposed mechanisms for INH-induced hepatic injury is oxidative stress [2]. Generation of free radicals damages the hepatocytes. The curative effect of extract can be explained by its antioxidant activity as demonstrated in the study. Previous studies demonstrate the presence of flavonoids and phenolic compounds in NAEE Linn [7]. The presence of these compounds might be responsible for the antioxidant activity.

\section{CONCLUSION}

The NAEE Linn. flowers in $200 \mathrm{mg} / \mathrm{kg}$ and $400 \mathrm{mg} / \mathrm{kg}$ doses showed therapeutically beneficial effect against INH-induced hepatotoxicity in rats.

\section{ACKNOWLEDGMENT}

AMU, Aligarh, Uttar Pradesh, India.

\section{CONFLICT OF INTEREST}

Nil.

\section{REFERENCES}

1. Raviglione MC, O'Brien RJ. In: Longo DA, Fauci AS, Kasper DL, Hauser SL, Jameson JL, Loscalzo J, editors. Harrison's Principles of Internal Medicine. $18^{\text {th }}$ ed. Ch. 165. United States of America: The McGraw-Hill Companies, Inc.; 2012. p. 1340.

2. Attri S, Rana SV, Vaiphei K, Sodhi CP, Katyal R, Goel RC, et al. Isoniazid- and rifampicin-induced oxidative hepatic injury-protection by N-acetylcysteine. Hum Exp Toxicol 2000;19:517-22.

3. Sarich TC, Youssefi M, Zhou T, Adams SP, Wall RA, Wright JM. Role of hydrazine in the mechanism of isoniazid hepatotoxicity in rabbits. 
Arch Toxicol 1996;70:835-40

4. Sarich TC, Zhou T, Adams SP, Bain AI, Wall RA, Wright JM. A model of isoniazid-induced hepatotoxicity in rabbits. J Pharmacol Toxicol Methods 1995;34:109-16.

5. Sodhi CP, Rana SV, Mehta SK, Vaiphei K, Attari S, Mehta S. Study of oxidative-stress in isoniazid-rifampicin induced hepatic injury in young rats. Drug Chem Toxicol 1997;20:255-69.

6. Arrigoni O, De Tullio MC. Ascorbic acid: Much more than just an antioxidant. Biochim Biophys Acta 2002;1569:1-9.

7. Marianne, Chrestella J, Ginting MA, Dalimunthe A, Nasution R. Hepatoprotective activity combination of Curanga fel-terrae lou leaves and Curcuma heyneana valeton and Zijp rhizome in rat induced by a combination of rifampin and isoniazid. Int J Pharm Pharm Sci 2017:9:23-8

8. Sankar M, Rajkumar J, Sridhar. Effect of heptoplus on isoniazid and rifampicin induced hepatotoxicity in liver cell lines. Int J Pharm Pharm Sci 2015;7:215-9.

9. Paharia AK, Pandurangan A. Evaluation of hepatoprotective activity of ethanolic extract of Nymphaea alba Linn flower in experimental rats. Int J Biomed Res 2013;4:349-54

10. Adnaik RS, Pai PT, Sapakal VD, Naikwade NS, Magdum CS. Anxiolytic activity of Vitex negundo Linn in experimental models of anxiety in mice. Int J Green Pharm 2009;3:243-7.

11. Robin D. Nymphaea odorata: White pond lily. Med Herb 2001;11:6-7.

12. Vergeera LH, Vander VG. Phenolic content of daylight-exposed and shaded floating leaves of water lilies (Nymphaeaceae) in relation to infection by fungi. Oecologia 1997;112:481-4.

13. Madhusudhan N, Lakshmi T, Gowtham KS, Ramakrishanan, Konda VG, Roy A, et al. In vitro antioxidant and free radical scavenging activity of aqueous and ethanolic flower extract of Nymphaea alba. Int J Drug Dev Res 2011;3:23-6.

14. Bose A, Ray SD, Sahoo M. Evaluation of analgesic and antioxidant potential of ethanolic extract of Nymphaea alba rhizome. Oxid Antioxid
Med Sci 2012;1:217-23

15. Singh G, Goyal R, Sharma PL. Pharmacological potential of Silymarin in combination with hepatoprotective plants against experimental hepatotoxicity in rats. Asian J Pharm Clin Res 2012;5 Suppl 1:164-7.

16. Reitman S, Frankel S. A colorimetric method for the determination of serum levels of glutamic oxaloacetic acid and pyruvic acid transaminases. Am J Clin Pathol 1957;10:394-9.

17. Marsh WH, Fingerhut B, Kirsch E. Adaption of alkaline phosphatase method for automatic colorimetric analysis. Clin Chem 1959;5:119-26.

18. Beers RF, Sizer IW. A spectrophotometric method for measuring the breakdown of hydrogen peroxide by catalase. J Biol Chem 1952;195:133-40.

19. Ellman GC. Tissue sulfhydryl groups. Arch Biochem Biophys $1959 ; 82: 70-7$

20. Niehans WG, Samuelsson D. Formation of malondialdehyde from phospholipids arrachidonate during microsomal lipid peroxidation. Eur J Biochem 1968;6:126-30.

21. Davidson CS. Guidelines for Detection of Hepatotoxicty Due to Drugs and Chemical. USA: NIH Publication, U.S. Department of Health and Education and Welfare NIH; 1979

22. Pumford NR, Halmes NC, Hinson JA. Covalent binding of xenobiotics to specific proteins in the liver. Drug Metab Rev 1997;29:39-57.

23. Ebadollahi-Natanzi A, Ghahremani MH, Monsef-Esfahani HR, Minaei MB, Nazarian H, Sabzevari O. Evaluation of antihepatotoxic effect of watercress extract and its fractions in rats. Int J Pharmacol 2010;6:896-902

24. Ramappa V, Aithal GP. Hepatotoxicity related to anti-tuberculosis drugs: Mechanisms and management. J Clin Exp Hepatol 2013;3:37-49.

25. Yesmin F, Rahman Z, Dewan JF, Helali AM, Rahman NIA, Ahmed AG, et al. Hepatoprotective role of aqueous and n-hexane extracts of Nigella sativa L. in experimental liver damage in rats. Asian J Pharm Clin Res 2013;6:205-9. 